\title{
PERSPEKTIF EKONOMI ISLAM TERHADAP WANITA PENCARI NAFKAH KELUARGA
}

\author{
Nurhadi \\ Sekolah Tinggi Agama Islam (STAI) Al-Azhar Pekanbaru Riau \\ Jl. K.H. Ahmad Dahlan No. 96 Sukajadi Pekanbaru 28124 Riau, Indonesia ... \\ Email: alhadijurnal@gmail.com; alhadicentre@yahoo.co.id
}

\begin{abstract}
Abstrak
Fenomena tenaga kerja wanita (TKW) yang mencari nafkah atau berkerja ke luar negeri demi kelangsungan hidup keluarga (suami dan anak-anaknya) sudah popular di masyarakat Indonesia, hal ini dikuatkan pula dengan tayangan sinetron di televisi nasional swasta yang berjudul "dunia terbalik" sebagai perwujudan fakta sosial ekonomi keluarga masyarakat Indonesia saat ini yang divisualkan berbentuk sinetron. Hal ini menjadi tanda tanya besar bagi pengamat sosial ekonomi dan praktisi keluarga sakinah atau keluarga Islam. Secara umum, tugas pokok dalam mencari nafkah keluarga dalam Islam dibebankan pada laki-laki (suami). Kendati dibenarkan perempuan (istri) mencari nafkah keluarga (berkerja) membantu perekonomian keluarga jika memang pendapatan suami tidak mencukupi untuk kebutuhan keluarga, dengan catatan bahwa perempuan tersebut dalam berkerja tidak mendatangkan aib, fitnah dan mudarat bagi dirinya dan kelangsungan rumah tangganya, serta dapat menjaga kehormatannya dengan selalu menutup aurat. Maka wanita pencari nafkah keluarga dalam pandangan ekonomi Islam dibolehkan, namun itu sebagai alternatif untuk mempertahankan kelangsungan hidup dan kehidupan rumah tangga dengan suami dan anak-anaknya, juga tidak melanggar kodratnya sebagai istri dan ibu bagi anakanaknya, untuk mengasuh serta memberiakan kasih sayang yang cukup.
\end{abstract}

Kata Kunci: Perspektif, Ekonomi Islam, Wanita, Pencari Nafkah, Keluarga.

\begin{abstract}
Abtract
The phenomenon of female workers (TKW) who make a living or work abroad for the survival of their families (husbands and children) is already popular in Indonesian society, this is also reinforced by soap opera shows on private national television entitled "the reverse world" as the realization of the socio-economic facts of the Indonesian family currently visualized in the form of soap operas. This is a big question mark for socio-economic observers and practitioners of sakinah family or Islamic families. In general, the main task in finding a family income in Islam is imposed on men (husbands). Although it is justified that women (wives) earn a living (working) to help the family economy if the husband's income is not sufficient for family needs, with the note that the woman in working does not bring shame, slander and harm to her and the continuity of her household, and can maintain her honor by always closing the genitals. So the family breadwinner in the view of Islamic economics is permitted, but it is an alternative to maintaining the survival and life of the household with his husband and children, nor does he violate his nature as wife and mother for his children, to nurture and give love enough.
\end{abstract}

Keywords: Perspective, Islamic Economy, Women, Livelihoods, Families. 


\section{A. PENDAhULUAN}

Pada saat asap hitam menyelimuti wajah-wajah wanita pada zaman Jahiliyah, maka cahaya Islam bersinar meneranginya. Islam menempatkan kedudukan wanita pada proporsinya dengan mengakui kemanusiaan wanita dan mengikis habis kegelapan yang dialami wanita sepanjang sejarah serta menjamin hak-hak wanita. Untuk menjelaskan kedudukan wanita dalam hukum Islam, dasar hukum yang harus dipegangi adalah kedua sumber utama hukum Islam, yaitu Al-Qur'an dan Sunnah. Dari dua sumber inilah diperoleh prinsip-prinsip yang pasti untuk melihat kedudukan wanita dalam Islam. Namun, harus kita maklumi bahwa prinsip-prinsip yang sudah digariskan oleh Al-Qur'an dan Sunnah terkadang dipraktikkan berbeda oleh umat Islam dalam kehidupan mereka sehari-hari. ${ }^{1}$ Bahkan harus disadari pula bahwa ayat-ayat Al-Qur'an dan hadishadis Nabi Saw yang sebenarnya menyuarakan masalah keadilan dan persamaan sering dipahami yang sebaliknya, sehingga di kalangan pemikir Islam (ulama) timbul perbedaan pendapat dalam berbagai permasalahan Islam, termasuk hukum Islam. Dalam posisi seperti ini, Al-Qur'an memberikan solusi yang tegas, bahwa jika di antara kita terjadi perbedaan pendapat maka seharusnya kita kembali merujuk kepada Allah swt dan Rasulullah saw untuk memutuskan perkaranya sebagaimana tertuang dalam al-Qur'an surah al-Nisa' ayat 59 (Departemen Agama 2015: 128). Karena itu, ketika dalam masyarakat

${ }^{1}$ Marzuki, Tinjauan Hukum Islam Tentang Wanita, (Artikel Pdf, t.vol, t.ed, t.th), 1-28, hlm. 1, artikel online Pdf dalam alamat wibesite, file:///C:/Documents\%20and\%20Settings/ACER/My \%20Documents/Downloads/Dr.+Marzuki,+M.Ag_.+T injauan+Hukum+Islam+tentang+Wanita.pdf, diakses 5 Juli 2019.
Islam berkembang opini yang berbedabeda mengenai hak dan kewajiban wanita, misalnya, maka kita harus kembali merujuk kepada ketentuanketentuan yang ada dalam Al-Qur'an dan Sunnah Nabi Muhammad Saw.

Perempuan merupakan bagian dari Islam dan perempuan mempunyai kedudukan penting dalam Islam. Islam sangat menghormati perempuan, Islam juga menganggap perempuan dan lakilaki berkedudukan sama. dimana Islam sangat menganjurkan pendidikan bagi perempuan, serta perempuan memiliki peran sosial di masyarakat luas terbukti dengan adanya public figure perempuan dibidang: politik, ekonomi, kesehatan dan sebagainya. Perempuan juga mempunyai peran dalam tatanan pengasuhan dalam rumah tangganya, karena perempuan merupakan pemimpin dalam rumah tangganya yang dijelaskan dalam sabda Rasullulah saw. ${ }^{2}$

Adat dan budaya partriarki terlanjur memposisiskan perempuan kesudut marginal, hegemoni laki-laki sebagai makhluk superioritas yang menganggap perempuan sebagai sub-ordinat dari kaum laki-laki (Abbas, 2012: 190). Tidak hanya itu, penafsiran para ulama selama ini, cenderung misoginis (menyudutkan perempuan) dan kental dengan warna bias gender. Karenanya, ketika agama ikut memberikan legitimasi terhadap kekerabatan partiarki dan pola pembagian kerja secara seksual, maka dengan sendirinya wacana gender akan bersentuhan dengan masalahmasalah keagamaan. ${ }^{3}$ Agama selama ini

${ }^{2}$ Sya'diyah, Halimah, "Perempuan dalam Perspektif Islam". (Purwokerto: Fakultas Agama Islam Universitas Muhammadiyah, 2014), iv

${ }^{3}$ Ali Yafie, Kemitrasejajaran Wanita-Pria: Perpektif Agama Islam dalam Bainar (Ed), Wacana Perempuan dalam Keindonesiaan dan Kemoderenan. (Yogyakarta: Cidesindo, 2011), 141 
dijadikan dalil untuk menolak konsep kesetaraan laki-laki dan perempuan, bahkan agama dianggap sebagai salah satu faktor yang menyebabkan langgengnya status quo perempuan sebagai the second sex. ${ }^{4}$

Islam tidak mengenal diskriminasi atau penganakemasan terhadap satu golongan tertentu. Semua orang memiliki kedudukan yang sama di hadapan Allah swt, baik laki-laki maupun perempuan. Adapaun yang membedakan adalah tingkat keimannya. Di dalam dunia Islam, wanita memiliki kedudukan yang mulia. Bahkan kelak ketika di surga, wanita dunia yang beriman lebih baik dan lebih cantik daripada bidadari. Sebab, tidaklah sama antara orang yang bekerja keras, beribadah, dikenai taklif (tugas kewajiban) serta musibah atau ujian yang harus dihadapi dengan makhluk yang diciptakan khusus untuk menghuni surga tanpa harus menghadapi semua itu. ${ }^{5}$

Isu emansipasi wanita atau kesetaraan jender sering digunakan oleh pihak-pihak tertentu untuk memojokkan Islam. Secara umum dikatakan bahwa telah terjadi diskriminasi antara laki-laki dan wanita dalam ajaran Islam. Melihat ajaran Islam siapa pun harus cermat dan teliti dalam memahaminya. Untuk mengetahui ajaran Islam, orang harus mampu melihatnya secara benar terhadap bagian-bagian yang ada dalam ajaran Islam agar bisa memahaminya secara obyektif. Dalam Islam ada bagian-bagian yang bersifat absolut dan ada yang bersifat relatif. Yang absolut adalah bagian yang merupakan ajaran-

${ }^{4}$ Nasaruddin Umar, Argumen Kesetaraan Jender: Perspektif Al-Qur'an. (Jakarta: Paramadina, 2010), 1

${ }^{5} \mathrm{M}$ Sarbini, "Hak-Hak Wanita dalam Fiqih Islam”, Al-Mashlahah Jurnal Hukum Islam dan Pranata Sosial Islam, STAI Al-Hidayah Bogor, t.vol, t.ed, (t.th), 609 ajaran pokok (ushul) yang ada dalam AlQur'an dan As-Sunnah. Sedangkan yang relatif adalah bagian ajaran yang merupakan hasil pemikiran manusia (ijtihad) tentang perincian dan penjabaran (furu') tentang cara pelaksanaan ajaran-ajaran pokok tersebut. $^{6}$

Permasalahan perbedaan antara lakilaki dan wanita sering disebut dengan istilah jender. Kata jender merupakan kosa kata yang terambil dari bahasa Inggris gender yang berarti jenis kelamin. Secara terminologis jender dimaknai sebagai "Interpretasi mental dan kultural terhadap perbedaan kelamin yakni laki-laki dan wanita". "Jender biasanya dipergunakan untuk menunjukkan pembagian kerja yang dianggap tepat bagi laki-laki dan wanita". Bisa juga dikatakan, jender adalah suatu konsep yang digunakan untuk mengidentifikasi perbedaan lakilaki dan wanita dilihat dari segi sosial budaya. $^{7}$

Kemajuan yang paling terasa dalam dunia pendidikan dewasa ini adalah semakin terbukanya peluang bagi perempuan untuk memasuki dunia pendidikan. Semua jenjang dan jenis pendidikan bebas dimasuki perempuan. Hampir-hampir tidak ditemukan lagi pendidikan khusus bagi laki-laki kecuali pendidikan di pesantren. Semua jurusan dan program studi, mulai dari humaniora sampai engenering terbuka dimasuki tanpa membedakan jenis kelamin. ${ }^{8}$

Kebebasan untuk memperoleh pendidikan ini, ternyata secara tidak senggaja memberi kesempatan kepada

${ }^{6}$ Zainul Muhibbin, "Wanita dalam Islam”, jsh Jurnal Sosial Humaniora, Vol 4 No.2, (2011), 109

${ }^{7}$ Zainul Muhibbin, "Wanita dalam Islam", 110

${ }^{8}$ Nelsi Arisandy, "Pendidikan dan Karir Perempuan dalam Perspektif Islam", Jurnal Marwah,Vol. XV No. 2, (2016), 125 
perempuan untuk memenangkan persaingan dalam memperoleh lapangan pekerjaan. Hal ini disebabkan pendidikan yang dianggap sebagai passport memperoleh pekerjaan, telah membuat kasta baru dalam kehidupan moderen bagi wanita. Orang dianggap cakap, mampu, dan layak diterima dalam suatu pekerjaan dengan melihat pendidikannya. Ditambah lagi, keberhasilan dalam proses pendidikan, atau kemampuan akademik yang dilambangkan Indek Prestasi Kumulatif (IPK) justru dijadikan pula sebagai barometer untuk pertimbangan dalam menerima calon pekerja. ${ }^{9}$

Kondisi ini telah menggeser persaingan untuk mendapatkan pekerjaan menjadi perseteruan untuk memperoleh tempat dalam dunia pendidikan. Merebut peluang dalam dunia pendidikan jauh lebih objektif, ilmiah, serta tidak deskriminatif terhadap gender. Dikarenakan persaingan memperoleh pendidikan lebih ditentukan oleh kemampuan akademik, justru posisi perempuan sangat diuntungkan. Sejak dari kecil, aktivitas anak perempuan sering dikontrol dibandingkan dengan anak laki-laki, dibatasi keluar rumah, sehingga mereka punya banyak waktu di rumah dan biasanya dimanfaatkannya untuk belajar. Sehingga wajarlah jika hasil belajar anak perempuan lebih baik dari anak laki-laki. Tujuh atau delapan orang dari 10 besar di sekolah-sekolah justru didominasi oleh anak perempuan. Sehinggga tidak mengherankan, banyak fakultas-fakultas sekarang ini, dibanjiri oleh mahasiswa perempuan. Mereka dapat mengalahkan dominasi laki-laki. ${ }^{10}$

${ }^{9}$ Nelsi Arisandy, "Pendidikan dan Karir Perempuan dalam Perspektif Islam", Jurnal Marwah, 125

${ }^{10}$ Nelsi Arisandy, "Pendidikan dan Karir Perempuan dalam Perspektif Islam", Jurnal Marwah,., 126
Seiring dengan dahsyatnya wacana tentang pembebasan (liberation) dan pemberdayaan (empowerment) kaum perempuan, dewasa ini fenomena kesetaraan gender telah menjadi isu penting dalam setiap agama, termasuk Islam (Sudrajat, t.th: 1). Di tengahtengah suasana domestikasi perempuan dan dominasi patriaki, kalangan feminis berusaha mengeluarkan perempuan dari pusat laki-laki. Istilah yang dipakai Munawar-Racham untuk perilaku ini adalah "ex-sentralisme". Kaum perempuan harus dibebaskan dari peran kulturalnya selama ini sebagai "kanca wingking". 11

Salah satu di antara pemikiran yang memberikan sumbangan terhadap relasi gender adalah adanya perbedaaan fisikbiologis antara laki-laki dan perempuan. Perbedaan itu antara lain terlihat pada aksesori organ reproduksi, seperti alat kelamin dan buah dada. ${ }^{12}$ Kenyataan biologis yang membedakan antara lakilaki dan perempuan ini telah melahirkan dua teori, yaitu teori nature dan teori nurture. $^{13}$

Dalam Al-Qur'an terdapat 114 surat, salah satu diantaranya adalah surat AnNisaa' (perempuan) terletak sesudah surat alBaqarah dan Ali-Imran. Demikian masalah wanita terdapat pula dalam ayat-ayat lainnya di dalam alQur'an, yang didalamnya membahas persoalan seputar wanita, dari obyektif-

\footnotetext{
${ }^{11}$ Budhy Munawar Rahman, Rekonstruksi Fiqh Perempuan dalam Konteks Perubahan Zaman”, dalam M. Hajar Dewantoro dan Asmawi (ed.), Rekonstruksi Fiqh Perempuan. (Yogyakarta: Penerbit Ababil, 2006), 24-25; Kamla Bashin, Menggugat Patriarki: Pengantar Tentang Persoalan Dominasi Terhadap Kaum Perempuan. (Yogyakarta: Bentang, 2007), v

${ }^{12}$ Nasaruddin Umar, Argumen Kesetaraan Jender: Perspektif Al-Qur'an, 38-42

13 Nasaruddin Umar, Argumen Kesetaraan Jender: Perspektif Al-Qur'an, xxi
} 
subyektif sampai positif negatif. ${ }^{14}$ Ini menunjukkan betapa penting dan mulianya kedudukan wanita dalam Islam, dimana secara terang-terangan telah dicantumkan dan dinamai dalam salah satu surat al-Qur'an, kitab suci agama Islam. Rasulullah saw. bersabda: "Surga di bawah telapak kaki ibu", didalamnya terkandung pengertian lain, bahwa wanita merupakan sumber daya manusia yang potensial untuk melahirkan surga (kesejahteraan). Kalau sumber daya ini diporakporandakan lewat kemasan yang baik dan bertujuan untuk kepentingan tertentu, maka kaum wanita bukan lagi memiliki surga di telapak kakinya, melainkan neraka. ${ }^{15}$

Kedudukan wanita dalam masyarakat bukanlah merupakan issue yang baru dan juga bukan sesuatu yang telah ditetapkan sepenuhnya. Posisi Islam dalam hal ini telah menjadi sorotan dunia Barat dengan tingkat objektivitas yang sangat kurang. Ajaran Islam bersumber dari AlQur'an dan As Sunnah (hadits). AlQur'an dan Hadits secara jelas dan tanpa bias menjadi sumber otentik dari segala hal yang berkenaan dengan agama Islam. ${ }^{16}$

Dunia pekerjaan sendiri terutama di Negara barat yang cenderung menggaungkan istilah persamaan gender, lebih banyak memprioritaskan pekerja perempuan dari laki-laki dengan bukti lebih banyaknya jumlah TKI dari kaum wanita (TKW), data tersebut dapat dilihat dalam Kompas Com, Menteri Tenaga Kerja mengatakan TKI samapai

\footnotetext{
${ }^{14}$ Ulya Kencana, "Wanita dalam Pandangan Agama dan Bangsa", Jurnal An Nisa'a, Vol. 7, No. 2, (2012), 87-88

${ }^{15}$ Abdullah A. Djawas, Dilema Wanita Karier; Menuju Keluarga Sakinah. (Yogyakarta: Ababil, 2010), 21

${ }^{16}$ Jamal A. Badawi, Kedudukan Wanita dalam Islam. (e-Book dari Maktabah Raudhah alMuhibbin, 2008), 3
}

pada akhir 2017 sebanyak 9 juta. $^{17}$ Demikian juga yang dilangsir oleh Data Bank Dunia mencatat terdapat 9 juta pekerja migran atau tenaga kerja asal Indonesia (TKI) yang tersebar di berbagai Negara. ${ }^{18}$ Dari jumlah 9 juta tersebut TKW sebanyak 60\% nya, hal ini bisa diambil dari data tahun 2013-2015 dan 2016. ${ }^{19}$ Sekaligus didukung dengan potret sinetron "Dunia Terbalik" yang menggambarkan social ekonomi keluarga, yang mana si istri mencari nafkah ke luar negeri untuk keluarga (suami dan anak-anaknya). Artikel ini akan menjelaskan mengenai kedudukan wanita dalam Islam dan bagaimana wanita yang mencari nafkah untuk keluarga dalam tinjauan ekonomi Islam?.

\section{B. PEMBAHASAN \\ Peran Wanita Menurut Islam.}

Al-Qur'an menunjukkan adanya kesetaraan gender. Dia menemukan lima variabel yang mendukung pendapatnya, yakni: 1) Laki-laki dan perempuan samasama sebagai hamba. Hal ini bisa dilihat

${ }^{17}$ Andri Donnal Putera dan Aprilia Ika, "Ini Data TKA di Indonesia dan Perbandingan dengan TKI di Luar Negeri", Kompas.Com, (23-04-2018), https://ekonomi.kompas.com/read/2018/04/23/154732 226/ini-data-tka-di-indonesia-dan-perbandingandengan-tki-di-luar-negeri, diakses 7Juli 2019.

${ }^{18}$ Adhitya Himawan, "PSI: TKA Hanya 1,4 Persen Dibanding 9 Juta TKI di Luar Negeri", Suara Com, (02-05-2018), https://www.suara.com/bisnis/2018/05/02/170315/psitka-hanya-14-persen-dibanding-9-juta-tki-di-luarnegeri, diakes 7 Juli 2019.

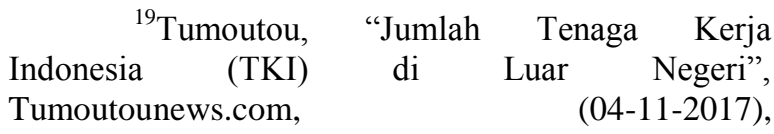
https://tumoutounews.com/2017/11/04/jumlah-tenagakerja-indonesia-tki-di-luar-negeri/, diakses 8 Juli 2019; lihat juga Badan Nasional Penempatan dan Perlindungan Tenaga Kerja Indonesia (BNP2TKI), "Jumlah TKI menurut jenis kelamin", Beritagar.Id, (2015-2016),

https://lokadata.beritagar.id/chart/preview/jumlah-tkimenurut-jenis-kelamin-1485345328, diakses 8 Juli 2019. 
misalnya dalam QS. al-Hujurat (49): 13 dan al-Nahl (16): 97; 2) Laki-laki dan perempuan sebagai khalifah di bumi. Hal ini terlihat dalam QS. al-Baqarat (2): 30 dan al-An'am (6): 165; 3) Laki-laki dan perempuan menerima perjanjian primordial seperti terlihat dalam QS. AlA'raf (7): 172; 4) Adam dan Hawa terlibat secara aktif dalam drama kosmis. Kejelasan ini terlihat dalam QS. alBaqarat (2): 35 dan 187, al-A'raf (7): 20, 22, dan 23; dan 5) Laki-laki dan perempuan berpotensi meraih prestasi seperti yang terlihat dalam QS. Ali 'Imran (3): 195, al-Nisa' (4): 124, alNahl (16): 97, dan al-Mu'min (40): $40 .^{20}$ Menurut Musthafa al-Siba'i, kedudukan wanita dalam Islam yang sama tingginya dengan kedudukan pria. Menurutnya, Islam mengatur kesamaan prinsip antara pria dan wanita sekurang-kurangnya dalam dua belas hal yang meliputi bidang kemanusiaan, sosial, maupun hak milik. Kedua belas prinsip itu adalah: 1) pria dan wanita sama dari segi kemanusiaannya; 2) Islam menghilangkan kutukan yang diberikan oleh ahli agama sebelum Islam kepada wanita. Islam menetapkan bahwa hukuman yang dikenakan kepada Adam, keluar dari surga, tidak berasal dari Hawa semata, tetapi dari mereka berdua; 3) Wanita mempunyai kecakapan untuk beragama dan untuk masuk surga jika ia berbuat baik dan akan disiksa jika ia berbuat jahat, sama seperti pria; 4) Islam

\footnotetext{
${ }^{20}$ Nasaruddin Umar, Argumen Kesetaraan Jender: Perspektif Al-Qur'an, 248-269; Yusuf AlQardawi, Khuthab wa Muhadarat al-Qaradawi 'an alMar'at, Alih bahasa oleh Tiar Anwar Bachtiar dengan judul "Qardhawi Bicara Soal Wanita". (Bandung: Arasy, 2013), 90-92; Muhammad Qutub, Islam the Misunderstood Religion, Alih bahasa oleh Fungky Kusnaedi Timur dengan judul "Islam Agama Pembebas". (Yogyakarta: Pustaka Pelajar, 2011), 2082010
}

mengikis rasa pesimis dan sedih pada waktu lahirnya bayi puteri, seperti tradisi bangsa Arab sebelum Islam; 5) Islam mengharamkan penguburan anak perempuan dalam keadaan hidup-hidup dan mengancam dengan keras terhadap pelakunya; 6) Islam memerintahkan agar menghormati wanita sebagai puteri, isteri, atau ibu; 7) Islam menganjurkan agar wanita diberi pelajaran seperti pria; 8) Islam memberikan hak bagi wanita dalam harta warisan, baik sebagai ibu, isteri, atau puteri, bagi yang sudah dewasa atau masih kecil, bahkan yang masih dalam kandungan; 9) Islam mengatur hak-hak suami dan menjadikan harta wanita sama dengan harta pria, kedudukan pria sebagai pemimpin dalam rumah tangga tidak boleh diktator dan zalim; 10) Islam mengatur masalah talak, mencegah sifat sewenang-wenang dan tindakan menang sendiri dari pria; 11) Islam membatasi poligami dan menetapkan jumlah isteri hanya boleh sampai empat saja; dan 12) sebelum dewasa, wanita ditetapkan harus berada dalam pemeliharaan walinya, dan kekuasaan wali itu berupa kekuasaan memelihara dan mendidik serta memerhatikan segala keperluannya dan mengembangkan harta miliknya. Setelah anak itu dewasa, Islam menetapkan bahwa ia mempunyai hak yang penuh dan memiliki kecakapan yang sempurna untuk memergunakan hartanya seperti pria. $^{21}$

Menurut Quraish Shihab bahwa seorang wanita memiliki hak-hak tersendiri yaitu antara lain: a) Hak di luar rumah b) Hak dan kewajiban belajar c) Hak di bidang politik. ${ }^{22}$

\footnotetext{
${ }^{21}$ Musthafa Al-Siba'iy, Al-Mar'at bain alFiqh wa al-Qanun. (Beirut: Al-Maktab al-Islamiy, 1984), 38-48

${ }^{22}$ Muhammad Qurais Shihab, Membumikan AlQur'an: Fungsi dan Peran Wahyu dalam Kehidupan Masyarakat. (Bandung: Mizan, 2006), 303;
} 
Menurut Jalaluddin Rakhmat bahwa wanita sesuai dengan fitrah kewanitannya. Islam menetapkan peranan-peranannya dalam berbagai status. Yaitu, wanita sebagai ibu, isteri, anak dan sebagai da'iyah. Status Ibu adalah paling utama, karena itu wanita mempunyai peran yang paling menentukan dalam kehidupan masyarakat. Status isteri memperteguh lembaga keluarga. Status anak menuntut pemeliharaan moral yang baik dan status da'iyah menuntut wanita untuk tampil di tengah masyarakat sebagai pelopor pembebasan, pembaharu dan kemajuan. Islam memandang dilema yang dihadapi wanita modern muncul akiabat pelanggaran terhadap peranan yang ditetapkan Islam. Lebih lanjut ia mengatakan bahwa wanita mempunyai hak yang sama denga pria. Tetapi fitrah kewanitaan yang dipunyainya membedakan peranan wanita dalam bidang sosial Islam mengatur peranan wanita tersebut. ${ }^{23}$

Kajian Fiqih Islam telah memberikan gambaran terperinci tentang hak-hak wanita di seluruh sisi kehidupannya, baik hak umum maupun khusus. Hak-hak yang banyak dibahas dalam fiqih Islam adalah hak-hak yang terkait dengan hukum, karena memang di sinilah ranah fiqih Islam. Hak-hak wanita yang banyak dibahas dalam Fiqih Islam antara lain: 1). Hak Sholat berjamaah; 2). Hak Menentukan Pilihan Pendamping ; 3). Hak Jima'; 4). Hak Mahar; 5). Hak Nafkah; 5). Waris; 6). Hak Jual Beli atau Bisnis; 7). Hak Baiat. Semua hak ini menggambarkan semua bab dalam masalah hukum yang melekat

Muhammad Qurais Shihab, Wawasan Al-Qur'an: Tafsir Maudhu'i atas Pelbagai Persoalan Umat. (Bandung: Mizan, 2007), 205

${ }^{23}$ Jalaluddin Rahmat, Islam Alternatif: Ceramah-Cermah di Kampus. (Bandung: Mizan, 2001), 137 dalam kehidupan wanita, baik di bidang publik, bidan ibadah maupun di bidang rumah tangga dan keuangan. ${ }^{24}$

Banyak sekali karya-karya para pemikir dan cendikiawan telah menguraikan secara garis besar posisi Islam mengenai kedudukan wanita dalam masyarakat ada bebrapa aspek, diantaranya: 1). Aspek Spiritual; 2). Aspek Sosial, diantaranya: sebagai anak dan orang dewasa, sebagai isteri dan sebagai ibu; 3). Aspek Ekonomi; 4). Aspek Politik. $^{25}$

\section{Tanggung Jawab Menafkahi Keluarga Menurut Islam.}

Sebelum membahas lebih lanjut tentang siapa yang berhak mencari nafkah dalam rumah tangga (keluarga), maka penulis akan mengetengahkan ayat yang berkaitan dengan hal tersebut, yaitu al-Qur'an surah An-Nisa ayat 34:

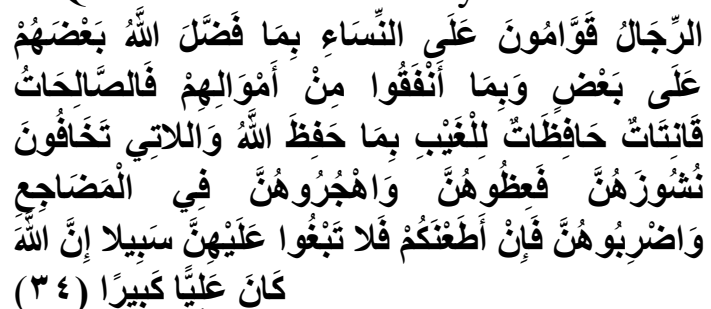

Artinya: Kaum laki-laki itu adalah pemimpin bagi kaum wanita, oleh karena Allah telah melebihkan sebahagian mereka (laki-laki) atas sebahagian yang lain (wanita), dan karena mereka (laki-laki) telah menafkahkan sebagian dari harta mereka. sebab itu Maka wanita yang saleh, ialah yang taat kepada Allah lagi memelihara diri ketika suaminya tidak ada, oleh karena Allah telah memelihara (mereka). wanita-wanita yang kamu khawatirkan nusyuznya, Maka nasehatilah mereka dan pisahkanlah mereka di tempat tidur mereka, dan

\footnotetext{
${ }^{24} \mathrm{M}$ Sarbini, "Hak-Hak Wanita dalam Fiqih Islam", 613-626

${ }^{25}$ Jamal A. Badawi, Kedudukan Wanita dalam Islam., 6-14
} 
pukullah mereka. kemudian jika mereka mentaatimu, Maka janganlah kamu mencari-cari jalan untuk menyusahkannya. Sesungguhnya Allah Maha Tinggi lagi Maha besar. ${ }^{26}$

Dari ayat diatas muncul pandangan yang stereotip bahwasanya kepemimpinan dalam rumah tangga itu ada di tangan suami (laki-laki). Dari kepemimpinan yang domestik ini kemudian melebar ke sektor publik, yang juga menempatkan laki-laki sebagai figur pemimpin. Pandangan yang demikian ini telah mendorong kalangan feminis untuk melihat kembali pemaknaan ayat tersebut, karena dilihatnya mengandung penafsiran yang bias gender.

Memahami ayat tersebut, mufassir seperti Zamakhsyari dan Alusi menyatakan bahwa dalam sebuah rumah tangga, suami (laki-laki) adalah pemimpin terhadap isterinya. Kalimat kunci yang menjadi landasan mereka adalah "al-rijalu qawwamna 'ala-nnisa ". Oleh Zamakhsyari kalimat tersebut ditafsirkan dengan "kaum lak-laki berfungsi sebagai yang memerintah dan melarang kaum perempuan sebagaimana pemimpin yang berfungsi terhadap rakyatnya". Dengan redaksi yang berbeda Alusi menyatakan hal yang sama dengan Zamakhsyari bahwa "tugas kaum laki-laki adalah memimpin kaum perempuan sebagaimana pemimpin memimpin rakyatnya yaitu dengan perintah, larangan, dan yang semacamnya". ${ }^{27}$

Alasan Zamakhsyari kenapa lakilaki yang memimpin perempuan dalam rumah tangga karena: pertama, kelebihan laki-laki atas perempuan. Kelebihan laki-

\footnotetext{
${ }^{26}$ Departemen Agama RI, Al-Qur'an dan Terjemahanya. (Semarang: Toha Putra, 2015), 123

${ }^{27}$ Sudrajat, Ajat, Beberapa Persoalan Perempuan dalam Islam, (t.tp: t.p, t.th), 6
}

laki itu adalah kelebihan akal, keteguhan hati, kemauan keras, kekuatan fisik, kemampuan menulis, naik kuda, memanah, menjadi nabi, ulama, kepala negara, imam salat, jihad, adzan, khutbah, i'tikaf, kesaksian dalam khudud dan qisas, mendapatkan ashabah dalam warisan, wali nikah, menjatuhkan talak, menyatakan ruju', boleh berpoligami, nama anak dinisbahkan kepadanya, berjenggot dan memakai sorban. Kedua, laki-laki membayar mahar dan mengeluarkan nafkah keluarga. ${ }^{28}$

Sementara itu Alusi mengemukakan alasannya berdasaarkan pada adanya dua sifat yang melekat pada laki-laki, yaitu sifat wahbi dan kasabi. Wahbi adalah kelebihan yang didapat dengan sendirinya (given) dari Tuhan, tanpa usaha; sedangkan kasabi adalah suatu kelebihan yang merupakan hasil ikhtiar. Menurut Alusi ayat tersebut tidak menjelaskan apa saja kelebihan laki-laki atas perempuan. Hal itu menurutnya mengisyaratkan bahwa kelebihan lakilaki atas perempuan sudah sangat jelas, sehingga tidak lagi memerlukan penjelasan yang rinci. ${ }^{29}$

Menurut Quraish Shihab ayat di atas merupakan legitimasi kepemimpinan laki-laki (suami) terhadap seluruh keluarganya dalam bidang kehidupan rumah tangga. Menurutnya kepemimpinan ini sesungguhnya tidak mencabut hak-hak isteri dalam berbagai segi, termasuk dalam hak pemilikan harta pribadi dan hak pengelolaannya walaupun tanpa persetujuan suami. Dalam pendapatnya kepemimpinan ini merupakan sebuah keniscayaan, karena keluarga dilihatnya sebagai sebuah unit

\footnotetext{
${ }^{28}$ Yunahar Ilyas, Feminisme dalam Kajian Tafsir Al-Qur'an Klasik dan Kontemporer. (Yogyakarta: Pustaka Pelajar, 2007), 77

${ }^{29}$ Yunahar Ilyas, Feminisme dalam Kajian Tafsir Al-Qur'an Klasik dan Kontemporer. 77
} 
sosial terkecil yang membutuhkan adanya seorang pemimpin. Alasan yang dikemukakannya, bahwa suami atau laki-laki memiliki sifat-sifat fisik dan psikis yang lebih dapat menunjang suksesnya kepemimpinan rumah tangga dibandingkan dengan isteri. Di samping itu suami (laki-laki) memiliki kewajiban memberi nafkah kepada isteri dan seluruh anggota keluarganya (Shihab, 2006: 310). Untuk memperkuat pendapatnya Quraish Shihab mengutip al-Qur'an ayat 228 dari surah alBaqarah:

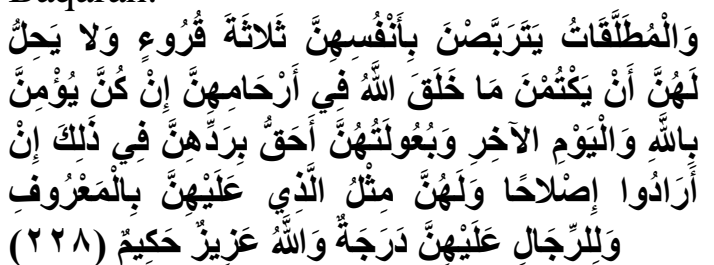

Artinya: Wanita-wanita yang ditalak handaklah menahan diri (menunggu) tiga kali quru'. tidak boleh mereka Menyembunyikan apa yang diciptakan Allah dalam rahimnya, jika mereka beriman kepada Allah dan hari akhirat. dan suami-suaminya berhak merujukinya dalam masa menanti itu, jika mereka (para suami) menghendaki ishlah. dan Para wanita mempunyai hak yang seimbang dengan kewajibannya menurut cara yang ma'ruf. akan tetapi Para suami, mempunyai satu tingkatan kelebihan daripada isterinya. dan Allah Maha Perkasa lagi Maha Bijaksana. ${ }^{30}$

Demikianlah pandangan beberapa mufassir tentang konsep kepemimpinan rumah tangga sebagaimana mereka fahami dari surat an-Nisa ayat 34 . Mereka sepakat dalam penafsirannya bahwa laki-laki (suami) adalah pemimpin perempuan (isteri) dengan dua alasan, yaitu: karena kelebihan laki-laki atas perempuan, dan karena nafkah yang mereka keluarkan untuk keperluan isteri

\footnotetext{
${ }^{30}$ Departemen Agama RI, Al-Qur'an dan Terjemahanya, 55
}

dan rumah tangga lainnya. Dalam perspektif yang lain, ayat tersebut di atas dipahami secara berbeda oleh kalangan feminis. Menurut Asghar Ali Engineer sebagaimana dikutip Ajat Sudrajat, misalnya, berpendapat bahwa surat alNisa ayat 34 itu tidak boleh dipahami lepas dari konteks sosial pada waktu ayat itu diturunkan. Menurutnya, struktur sosial pada zaman nabi tidaklah benarbenar mengakui kesetaraan (equality) antara laki-laki dan perempuan. Oleh karena itu tidak boleh mengambil pandangan yang semata-mata bersifat teologis, tetapi harus menggunakan pandangan sosio-teologis. ${ }^{31}$

Dalam pandangan Asghar keunggulan laki-laki bukan merupakan keunggulan jenis kelamin, tetapi berupa keunggulan fungsional, karena laki-laki mencari nafkah dan membelanjakan hartanya untuk perempuan (dan keluarga). Fungsi sosial yang diemban oleh laki-laki itu seimbang dengan fungsi sosial yang diemban oleh perempuan, yaitu melakukan tugas-tugas domestik dalam rumah tangga. Alasannya adalah karena perempuan ketika itu masih sangat rendah kesadaran sosialnya dan pekerjaan domestik sebagai kewajiban perempuan. Sementara laki-laki memandang dirinya sendiri lebih unggul karena kekuasaan dan kemampuan mereka mencari nafkah dan membelanjakannya untuk perempuan. $^{32}$

Berbeda dengan Asghar adalah Aminah Wadud dan ia menyetujui laki-

${ }^{31}$ Asghar Ali Engineer, "Perempuan dalam Syari'ah: Perspektif Feminis dalam Penafsiran Islam", Jurnal Ilmu dan Kebudayaan Ulumul Qur'an, Nomor 3, Vol. V (1994), 61.

${ }^{32}$ Asghar Ali Engineer, "Perempuan dalam Syari'ah: Perspektif Feminis dalam Penafsiran Islam", Jurnal Ilmu dan Kebudayaan Ulumul Qur'an, Nomor 3, Vol. V (1994), 61.

; Sudrajat, Ajat, Beberapa Persoalan Perempuan dalam Islam, 8 
laki sebagai pemimpin atas perempuan dalam rumah tangga. Namun, dalam hal ini ia memberikan dua persyaratan, yaitu jika laki-laki punya atau sanggup membuktikan kelebihannya, dan jika laki-laki mendukung perempuan dengan menggunakan harta bendanya. ${ }^{33}$

Pendapat yang berbeda tentang penafsiran ayat di atas dikemukakan juga oleh Masdar F. Mas'udi, dalam bukunya $^{34}$ dengan mengutip Tafsir Jalalain, kata qawwâmûna 'ala an-nisa', tidak semata ditafsirkan dengan menguasasi atau mensultani perempuan, melainkan dapat pula ditafsirkan dengan penopang atau penguat perempuan. ${ }^{35}$ Karena arti yang demikian ternyata ditemukan dalam surah al-Nisa (4) ayat $135 .^{36}$ dan al-Maidah (5) ayat $8 .{ }^{37}$ Sehingga dengan demikian ayat itu artinya adalah "kaum laki-laki adalah penguat dan penopang kaum perempuan dengan (bukan karena) kelebihan yang satu atas yang lain dan dengan (bukan karena) nafkah yang mereka berikan". Dengan pengertian seperti itu, maka secara normatif sikap suami (laki-laki) kepada isteri (perempuan) bukanlah "menguasai" atau "mendominasi" dan cenderung memaksa, melainkan mendukung dan mengayomi. Pengertian seperti diatas lebih sesuai dengan prinsip mu'asyarah bil ma'ruf (Q.S. An-Nisa (4)

\footnotetext{
${ }^{33}$ Amina Wadud, Qur'an Menurut Perempuan: Meluruskan Bias Gender dalam Tradisi Tafsir, Terjemahan Abdullah Ali. (Jakarta: PT, Serambi Ilmu Semesta, 2011), 93-94

${ }^{34}$ Masdar F. Mas'udi, Islam \& Hak-Hak Reproduksi Perempuan: Dialog Fiqh Pemberdayaan. (Bandung: Mizan, 2010), 61-62

${ }^{35}$ Imam Jalalain, Tafsir Jalalain. (Mesir: Maktabah ilmiyah, t.th), 76; Sudrajat, Ajat, Beberapa Persoalan Perempuan dalam Islam, 9

${ }^{36}$ Departemen Agama RI, Al-Qur'an dan Terjemahanya, 144

${ }^{37}$ Departemen Agama RI, Al-Qur'an dan Terjemahanya 159
}

ayat 19). dan prinsip saling melindungi (Q.S. Al-Baqarah (2) ayat 187).

Dari uraian diatas tentang posisi laki-laki sebagai pemimpin bagi keluarga dan kaum wanita, maka kewajiban mencari nafkah dalam Islam adalah kaum laki-laki sebagai kepala keluarga. Namun menurut Masdar F. Mas'udi, jika suami benar-benar bisa menopang dalam membiayai kehidupan keluarga dan membuktikan kelebihankelebihannya di depan istri dan anakanak (keluarga), maka laki-laki (suami) sebagai pencari nafkah dalam Islam, tetapi jika tidak, perempuan (istri) akan tampil didepan untuk menopang dan mencari nafkah untuk keluarga sebagai bukti taat dan patuh kepada suami, demi kelangsungan hidup dan kehidupan keluarga (suami dan anak-anaknya). Maknanya wanita dibenarkan keluar rumah kerja mencari nafkah jika suami benar-benar tidak dapat memenuhi kebutuhan keluarga sesuai syariat, misalnya sakit, sudah terlalu tua dan uzhur lainya, hal ini sesuai dalil ayat 187 surah Al-Baqarah diatas. Akan tetapi ada yang perlu digaris bawahi bahwa jika tidak dikhawatirkan terjadi hal-hal yang dapat merusak dirinya dan keluarganya.

Laki-laki dalam Islam bertanggung jawab sepenuhnya dalam memelihara isteri, anak-anak, dan dalam beberapa kasus keluarga yang membutuhkan, khususnya perempuan. Kewajiban ini tidak terlepas atau berkurang karena kekayaan isterinya atau karena pendapatan yang diperoleh isterinya dari bekerja, sewa-menyewa, keuntungan, atau pendapatan halal lainnya. ${ }^{38}$

Kewajiban mencari nafkah untuk keluarga dalam Islam dilimpahakan kepada laki-laki sebagai kepala keluarga dan pemimpin dalam rumah tangga.

Islam, 12
${ }^{38}$ Jamal A Badawi, Kedudukan Wanita dalam 
Maka malulah sebagai laki-laki jikalau justru sebaliknya, yaitu istrinya yang mencari nafkah untuknya dan anakanaknya, hal tersebut bala dan aib yang cukup menghinakan bagi kaum laki-laki, apalagi sampai dibawah kendali seorang wanita (istri) dalam rumah tangga, ini merupakan zaman (keadaan) yang paling na'if bagi laki-laki untuk mencari amal ibadah dari mencari nafkah untuk keluarga, wajar kalau ada istilah "dunia sudah terbalik".

\section{Berkerja Mencari Nafkah Keluarga Bagi Perempuan dalam Perspektif Ekonomi Islam.}

Mengenai hak wanita untuk bekerja, harus ditegaskan sebelumnya bahwa Islam memandang tugasnya dalam masyarakat sebagai ibu dan isteri sebagai peranan yang sangat suci dan penting. Tidak pembantu atau perawat anak dapat menggantikan tugas seorang ibu sebagai pendidik anak pada masa pertumbuhan dengan kebebasan kompleks dan membesarkannya dengan hati-hati. Tugas yang mulia dan vital ini, yang secara luas membentuk masa depan bangsa, tidak dapat dikatakan "tidak berbuat apa-apa

Namun demikian, tidak ada satupun ketetapan dalam Islam yang melarang wanita bekerja manakala ada kebutuhan untuk itu, khususnya pada pekerjaan yang sesuai dengan kewanitaanya dan dimana masyarakat lebih membutuhkannya. Contoh dari profesi ini adalah perawat, pengajar (khususnya bagi anak-anak) dan pengobatan. Lebih lanjut, tidak ada batasan mengambil manfaat dari keahlian khusus wanita dalam bidang apapun. Bahkan dalam posisi sebagai hakim, dimana ada kecenderungan untuk meragukan kemampuan wanita pada posisi tersebut mengingat sifat emosional alamiahnya, kita temukan sebelumnya para ulama seperti Abu Hanifa dan At-Thabari menegaskan hal itu tidak mengapa. ${ }^{39}$

Berkaitan dengan wanita berkerja mencari nafkah untuk keluarga menurut ekonomi Islam, maka sebelum menyimpulkanya, penulis merasa perlu untuk sedikit memaparkan bagaimana pada zaman Rasulullah saw dan sahabat para wanita (istri) pada saat itu. Misalnya Ummu Salamah (istri Nabi), Shafiyah, Laila Al-Ghaffariyah, Ummu Sinam Al-Aslamiyah, dan lain-lain, tercatat sebagai tokoh-tokoh yang terlibat dalam peperangan. ${ }^{40}$

Isteri Rasulullah saw, Khadidjah R.a adalah seorang perempuan yang aktif dalam dunia bisnis. Beliau adalah figur perempuan karier pertama kali dalam sejarah Islam bahkan Rasulullah saw telah melakukan akad mudharabah (akad bagi keuntungan) bersamanya. ${ }^{41}$

Sayyidah Khadijah juga melakukan ekspor-impor komoditas perdagangannya secara internasional. Kafilah usahanya membentang dari negeri Yaman ke negeri Syiria, dan terus bekerja di musim panas dan dingin. Beliau termasuk orang pertama yang menghilangkan sekat-sekat dan membuka pintu selebar-lebarnya bagi perempuan untuk terjun di dunia bisnis. Beliau melakukan kegiatan bisnis jauh sebelum beliau menikah dengan Rasulllah saw. Setelah menikah, kegiatan bisnisnya dilanjutkan dan direstui oleh suaminya. Bahkan harta hasil jerih payah bisnis Khadijah R.a itu amat banyak menunjang dakwah di masa awal. Di masa itu, belum ada sumbersumber dana penunjang dakwah yang bisa diandalkan. Satu-satunya adalah

\footnotetext{
${ }^{39}$ Jamal A Badawi, Kedudukan Wanita dalam Islam, 12

${ }^{40}$ Nelsi Arisandy, "Pendidikan dan Karir Perempuan dalam Perspektif Islam", 132

${ }^{41}$ Nelsi Arisandy, "Pendidikan dan Karir Perempuan dalam Perspektif Islam”, 132
} 
dari kantong isteri beliau yang dikenal sebagai busisness women yang ulung.

Tentu tidak bisa dibayangkan kalau sebagai pebisnis, sosok Khadijah adalah tipe perempuan rumahan yang tidak berpendidikan. Sebab bila demikian, bagaimana dia bisa menjalankan bisnisnya itu dengan baik, sementara dia tidak punya akses informasi sedikit pun di balik tembok rumahnya. Di sini kita bisa paham bahwa seorang isteri Nabi saw sekalipun punya kesempatan untuk keluar rumah mengurus bisnisnya Sepeninggal Khadijah, Rasulullah saw beristrikan Aisyah R.a, seorang perempuan cerdas, muda dan cantik yang kiprahnya di tengah masyarakat tidak diragukan lagi. Posisinya sebagai seorang istri tidak menghalanginya dari aktif di tengah masyarakat. Semasa Rasulullah saw masih hidup, beliau sering kali ikut keluar Madinah ikut berbagai operasi peperangan. Dan sepeninggal Rasulullah saw, Aisyah adalah guru dari para shahabat yang mampu memberikan penjelasan dan keterangan tentang ajaran Islam. Bahkan Aisyah R.a pun tidak mau ketinggalan untuk ikut dalam peperangan. Sehingga perang itu disebut dengan perang unta, karena saat itu Aisyah R.a naik seekor unta. $^{42}$

Di samping itu, para perempuan pada masa Nabi saw aktif pula dalam berbagai bidang pekerjaan. Ada yang bekerja sebagai perias pengantin, seperti Ummu Salim binti Malhan yang merias, antara lain, Shafiyah bin Huyay istri Nabi Muhammad saw. Ada juga yang menjadi perawat atau bidan, dan sebagainya. Tercatat sebagai seorang yang sangat sukses. Demikian juga Qilat Ummi Bani Anmar yang tercatat sebagai seorang perempuan yang pernah datang

\footnotetext{
${ }^{42}$ Nelsi Arisandy, "Pendidikan dan Karir Perempuan dalam Perspektif Islam”, , 133
}

kepada Nabi saw untuk meminta petunjuk-petunjuk dalam bidang jualbeli. Dalam kitab Thabaqat Ibnu Sa'ad, kisah perempuan tersebut diuraikan, di mana ditemukan antara lain pesan Nabi saw kepadanya menyangkut penetapan harga jual-beli. Nabi saw memberi petunjuk kepada perempuan ini dengan sabdanya: "Apabila anda akan membeli atau menjual sesuatu, maka tetapkanlah harga yang anda inginkan untuk membeli atau menjualnya, baik kemudian anda diberi atau tidak". (Maksud beliau jangan bertele-tele dalam menawar atau menawarkan sesuatu). ${ }^{43}$

Istri Nabi saw, Zainab binti Jahsy, juga aktif bekerja sampai pada menyamak kulit binatang, dan hasil usahanya itu beliau sedekahkan. Raithah, istri sahabat Nabi Abdullah ibn Mas'ud, sangat aktif bekerja, karena suami dan anaknya ketika itu tidak mampu mencukupi kebutuhan hidup keluarga ini. Al-Syifa', seorang perempuan yang pandai menulis, ditugaskan oleh Khalifah Umar R.a sebagai petugas yang menangani pasar kota Madinah.

Perempuan-perempuan yang diceritakan di atas adalah sedikit dari banyak contoh yang terjadi pada masa Rasul saw dan sahabat beliau menyangkut keikutsertaan perempuan dalam berbagai bidang usaha dan pekerjaan. Di samping yang disebutkan di atas, perlu juga digarisbawahi bahwa Rasul saw banyak memberi perhatian serta pengarahan kepada perempuan agar menggunakan waktu sebaik-baiknya dan mengisinya dengan pekerjaan-pekerjaan yang bermanfaat. Beliau bersabda: "Sebaik-baik "permainan" seorang perempuan Muslimah di dalam rumahnya adalah memintal/menenun".

\footnotetext{
${ }^{43}$ Nelsi Arisandy, "Pendidikan dan Karir Perempuan dalam Perspektif Islam”, 133.
} 
(HR. Abu Nu'aim dari Abdullah bin Rabi’ Al-Anshari).

Aisyah R.a diriwayatkan pernah berkata: "Alat pemintal di tangan perempuan lebih baik daripada tombak di tangan lelaki." Tentu saja tidak semua bentuk dan ragam pekerjaan yang terdapat pada masa kini telah ada pada masa Nabi saw. Namun, sebagaimana telah diuraikan di atas, ulama pada akhirnya menyimpulkan bahwa perempuan dapat melakukan pekerjaan apa pun selama ia membutuhkannya atau pekerjaan itu membutuhkannya dan selama norma-norma agama dan susila tetap terpelihara. ${ }^{44}$

Dari paparan tersebut dapat dijawab bahwa wanita berkerja mencari nafkah untuk keluarga dibolehkan dalam pandangan Islam sesuai dengan riwayat para istri Rasul saw dan istri para sahabat. Namun perlu dibatasi pekerjaanya, jika keilmuan wanita (istri) sangat dibutuhkan oleh masyarakat, maka diharuskan untuk berkerja keluar rumah selam tidak terjadi fitnah. Akan tetapi jika skill dan ilmu yang dimiliki wanita (istri) tidak terlalu dibutuhkan masyarakat, maka wanita (istri) berkerja dirumah itulah yang paling baik. Kemudian jika suami, dari hasil (gaji) pekerjaannya tidak dapat memenuhi kebutuhan primer (pokok) keluarga, maka istri boleh membantu berkerja dirumah maupun diluar rumah. Pendeknya wanita berkerja mencari nafkah keluarga pandangan ekonomi Islam dibolehkan sebagai jalan altenatif untuk kelangsungan hidup dan kehidupan rumah tangga dan keluarga sebagaimana dalam surah al-Jumu'ah ayat $10,{ }^{45}$ namun bukan meninggalkan

\footnotetext{
${ }^{44}$ Nelsi Arisandy, "Pendidikan dan Karir Perempuan dalam Perspektif Islam", 134

${ }^{45}$ Departemen Agama RI, Al-Qur'an dan Terjemahanya, 933
}

keluarga di negeri orang. Maka sinetron "dunia terbalik" yang mana para wanita kerja keluar negeri mencari nafkah untuk keluarga (suami dan anak-anak) tidak sesuai dengan hukum Islam dan ekonomi Islam, hak ini akan merusak tatanan sosial rumah tangga dan akan terlepas dari unsur keluarga bahagia sakinah mawaddah warahmah, hal sesuai dengan hadis Nabi saw tentang ciri-ciri keluarga bahagia adalah rezekinya ada dinegeri sendiri, abda Rasul saw: Empat perkara termasuk dari kebahagiaan, yaitu wanita (istri) yang shalihah (kalau untuk wanita tentunya lelaki/suami yg Sholeh), tempat tinggal yang luas/ lapang, tetangga yang shalih, dan tunggangan (kendaraan) yang nyaman.Dan empat perkara yang merupakan kesengsaraan yaitu tetangga yang jelek, istri yang jelek (tidak shalihah) (kalau buat wanita yg bikin sengsara adalah suami yg brengsek), kendaraan yang tidak nyaman, dan tempat tinggal yang sempit." (HR. Ibnu Hibban). ${ }^{46}$

\section{KESIMPULAN}

Wanita berkerja mencari nafkah untuk keluarga dibolehkan dalam pandangan Islam sesuai dengan riwayat para istri Rasul saw dan istri para sahabat. Namun perlu dibatasi pekerjaanya, jika keilmuan wanita (istri) sangat dibutuhkan oleh masyarakat, maka diharuskan untuk berkerja keluar rumah selam tidak terjadi fitnah. Akan tetapi jika skill dan ilmu yang dimiliki wanita (istri) tidak terlalu dibutuhkan masyarakat, maka wanita

\footnotetext{
${ }^{46}$ Imam Ibnu Hibban, Al-Mawarid. (Lebanon: Dar Ilmiyah, t.th), 302; Asy-Syaikh Muqbil, AlJami'ush Shahih, (Cairo: Maktbah Alamiyah, t.th), juz 3, 57; Asy-Syaikh Nasiruddin Al-Albani, Silsilah Al-Ahadits Ash-Shahihah, (Riyadh: Maktabah Sunnah, 2001), No. 282.
} 
(istri) berkerja dirumah itulah yang paling baik. Kemudian jika suami, dari hasil (gaji) pekerjaannya tidak dapat memenuhi kebutuhan primer (pokok) keluarga, maka istri boleh membantu berkerja dirumah maupun diluar rumah. Pendeknya wanita berkerja mencari nafkah keluarga pandangan ekonomi Islam dibolehkan sebagai jalan altenatif untuk kelangsungan hidup dan kehidupan rumah tangga dan keluarga, namun bukan meninggalkan keluarga di negeri orang. Maka sinetron "dunia terbalik" yang mana para wanita kerja keluar negeri mencari nafkah untuk keluarga (suami dan anak-anak) tidak sesuai dengan hukum Islam dan ekonomi Islam, hak ini akan merusak tatanan sosial rumah tangga dan akan terlepas dari unsur keluarga bahagia sakinah mawaddah warahmah, hal sesuai dengan hadis Nabi saw tentang cirri-ciri keluarga bahagia adalah rezekinya ada dinegeri sendiri.

\section{DAFTAR PUSTAKA}

Abbas, "Perempuan dalam Pandangan Agama (Studi Gender dalam Perspektif Islam)", Jurnal Muwazah, Volume. 4, Nomor. 2, (2012), 189-198

Al-Albani, Asy-Syaikh Nasiruddin, Silsilah Al-Ahadits Ash-Shahihah, (Riyadh: Maktabah Sunnah, 2001), No. 282).

Al-Qardawi, Yusuf, Khuthab wa Muhadarat al-Qaradawi 'an alMar'at, Alih bahasa oleh Tiar Anwar Bachtiar dengan judul "Qardhawi Bicara Soal Wanita". Bandung: Arasy, 2013.

Al-Siba'iy, Musthafa, Al-Mar'at bain al-Fiqh wa al-Qanun. Beirut: AlMaktab al-Islamiy, 1984.

Arisandy, Nelsi, "Pendidikan dan Karir Perempuan dalam Perspektif Islam",
Jurnal Marwah,Vol. XV No. 2, (2016), 125-13

Badawi, Jamal A., Kedudukan Wanita dalam Islam. e-Book dari Maktabah Raudhah al- Muhibbin, 2008.

Bashin, Kamla, Menggugat Patriarki: Pengantar Tentang Persoalan Dominasi Terhadap Kaum Perempuan. Yogyakarta: Bentang, 2007.

Departemen Agama RI, Al-Qur'an dan Terjemahanya. Semarang: Toha Putra, 2015.

Djawas, Abdullah A., Dilema Wanita Karier; Menuju Keluarga Sakinah. Yogyakarta: Ababil, 2010.

Engineer, Asghar Ali, "Perempuan dalam Syari'ah: Perspektif Feminis dalam Penafsiran Islam”, Jurnal Ilmu dan Kebudayaan Ulumul Qur'an, Nomor 3, Vol. V (1994)

Hibban, Imam Ibnu, Al-Mawarid. Lebanon: Dar Ilmiyah, t.th.

Himawan, Adhitya, "PSI: TKA Hanya 1,4 Persen Dibanding 9 Juta TKI di Luar Negeri”, Suara Com, (02-052018),

https://www.suara.com/bisnis/2018/ 05/02/170315/psi-tka-hanya-14persen-dibanding-9-juta-tki-di-luarnegeri, diakes 7 Juli 2019.

Ilyas, Yunahar, Feminisme dalam Kajian Tafsir Al-Qur'an Klasik dan Kontemporer. Yogyakarta: Pustaka Pelajar, 2007.

Jalalain, Imam, Tafsir Jalalain. Mesir: Maktabah ilmiyah, t.th.

Kencana, Ulya, "Wanita dalam Pandangan Agama dan Bangsa", Jurnal An Nisa'a, Vol. 7, No. 2, (2012), 87-102

Marzuki, Tinjauan Hukum Islam Tentang Wanita, (Artikel Pdf, t.vol, t.ed, t.th), 1-28, hlm. 1, artikel online Pdf dalam alamat wibesite, file:///C:/Documents\%20and\%20Set 
tings/ACER/My\%20Documents/Do wnloads/Dr.+Marzuki,+M.Ag .+Tin jauan+Hukum+Islam+tentang+Wani ta.pdf, diakses 5 Juli 2019.

Mas'udi, Masdar F., Islam \& Hak-Hak Reproduksi Perempuan: Dialog Fiqh Pemberdayaan. Bandung: Mizan, 2010.

Muhibbin, Zainul, "Wanita dalam Islam", jsh Jurnal Sosial Humaniora, Vol 4 No.2, (2011), 109-121

Muqbil, Asy-Syaikh, Al-Jami'ush Shahih, (Cairo: Maktbah Alamiyah, t.th), juz 3

Nasaruddin, Argumen Kesataraan Gender dalam Perspektif Al-Qur'an. Jakarta: Paramadina, 2010.

Putera, Andri Donnal dan Aprilia Ika, "Ini Data TKA di Indonesia dan Perbandingan dengan TKI di Luar Negeri", Kompas.Com, (23-042018),

https://ekonomi.kompas.com/read/2 018/04/23/154732226/ini-data-tkadi-indonesia-dan-perbandingandengan-tki-di-luar-negeri, diakses 7Juli 2019.

Qutub, Muhammad, Islam the Misunderstood Religion, Alih bahasa oleh Fungky Kusnaedi Timur dengan judul "Islam Agama Pembebas". Yogyakarta: Pustaka Pelajar, 2011.

Rahman, Budhy Munawar, Rekonstruksi Fiqh Perempuan dalam Konteks Perubahan Zaman", dalam M. Hajar Dewantoro dan Asmawi (ed.), Rekonstruksi Fiqh Perempuan. Yogyakarta: Penerbit Ababil, 2006.

Rahmat, Jalaluddin, Islam Alternatif: Ceramah-Cermah di Kampus. Bandung: Mizan, 2001.

Sarbini, M., "Hak-Hak Wanita dalam Fiqih Islam", Al-Mashlahah Jurnal Hukum Islam dan Pranata Sosial
Islam, STAI Al-Hidayah Bogor, t.vol, t.ed, (t.th), hlm. 609-627, file:///C:/Documents\%20and\%20Set tings/ACER/My\%20Documents/Do wnloads/184-369-1-SM.pdf, diakses 7 Juli 2019.

Shihab, Muhammad Qurais, Membumikan Al-Qur'an: Fungsi dan Peran Wahyu dalam Kehidupan Masyarakat. Bandung: Mizan, 2006.

Shihab, Muhammad Qurais, Wawasan Al-Qur'an: Tafsir Maudhu'i atas Pelbagai Persoalan Umat. Bandung: Mizan, 2007.

Sudrajat, Ajat, Beberapa Persoalan Perempuan dalam Islam, (t.tp: t.p, t.th),

16,file:///C:/Documents\%20and\%20

Settings/ACER/My\%20Documents/ Downloads/Beberapa+Persoalan $+\mathrm{Pe}$ rempuan+dalam+Islam.pdf, diakses 7 Juli 2019

Sya'diyah, Halimah, "Perempuan dalam Perspektif Islam”. Purwokerto: Fakultas Agama Islam Universitas Muhammadiyah, 2014.

Tumoutou, "Jumlah Tenaga Kerja Indonesia (TKI) di Luar Negeri”, Tumoutounews.com, (04-11-2017), https://tumoutounews.com/2017/11/ 04/jumlah-tenaga-kerja-indonesiatki-di-luar-negeri/, diakses 8 Juli 2019; lihat juga Badan Nasional Penempatan dan Perlindungan Tenaga Kerja Indonesia (BNP2TKI), "Jumlah TKI menurut jenis kelamin", Beritagar.Id, (20152016),

https://lokadata.beritagar.id/chart/pr eview/jumlah-tki-menurut-jeniskelamin-1485345328, diakses 8 Juli 2019.

Umar, Nasaruddin, Argumen Kesetaraan Jender: Perspektif Al-Qur'an. Jakarta: Paramadina, 2010. 
Umar, Nasaruddin, Argumen Kesetaraan Jender: Perspektif Al-Qur'an. Jakarta: Paramadina, 2009.

Wadud, Amina, Qur'an Menurut Perempuan: Meluruskan Bias Gender dalam Tradisi Tafsir, Terjemahan Abdullah Ali. Jakarta: PT, Serambi Ilmu Semesta, 2011.

Yafie, Ali, Kemitrasejajaran WanitaPria: Perpektif Agama Islam dalam Bainar (Ed), Wacana Perempuan dalam Keindonesiaan dan Kemoderenan. Yogyakarta: Cidesindo, 2011. 